\title{
Knights, Knaves or Pawns? Human Behaviour and Social Policy
}

\author{
JULIAN LE GRAND*1
}

(Received 20.7.95; Accepted 27.10.95)

\section{ABSTRACT}

There are two fundamental changes currently under way in the welfare state. These are the development of quasi-markets in welfare provision, and the supplementation of 'fiscal' welfare by 'legal' welfare: policies that rely on redistributing income through regulation and other legal devices, instead of through the tax and social security system. This article argues that these changes are in part the result of a fundamental shift in policy-makers' beliefs concerning human motivation and behaviour. People who finance, operate and use the welfare state are no longer assumed to be either public spirited altruists (knights) or passive recipients of state largesse (pawns); instead they are all considered to be in one way or another self-interested (knaves). However, since neither the 'new' nor the 'old' set of assumptions are based on evidence, policies based on the new set are as likely to fail as those based on the old. What is needed are 'robust' policies that are not dependent on any simple view of human behaviour.

'In contriving any system of government, and fixing the several checks and controls of the constitution, every man ought to be supposed a knave and to have no other end, in all his actions, than private interest. By this interest, we must govern him and, by means of it, notwithstanding his insatiable avarice and ambition, co-operate to the public good.' (David Hume, 1875, pp. 117-18)

'If it is accepted that man has a sociological and biological need to help, then to deny him opportunities to express this need is to deny him the freedom to enter into gift relationships.' (Richard Titmuss, 1971, p. 243)

There are two fundamental changes currently under way in the welfare states of Britain and other developed countries, each rather different from the other. One - the replacement of the state provision of

\footnotetext{
* Richard Titmuss Professor of Health Policy, Department of Social Policy and Administration, London School of Economics, and Professorial Fellow, Kings Fund Policy Institute.
} 
services by 'quasi-market' provision - is by now well known. It involves the introduction of competition into the delivery of social services such as education, health care and social care, and, as its label suggests, is pro-market in nature. The second change has been less widely remarked. It concerns the other side of the welfare state - social security or, more generally, the redistribution of income - and may be described as the supplementation of 'fiscal' by 'legal' welfare. Legal welfare involves the use of regulation or legislation to intervene in market outcome, and could be interpreted, at least in part, as anti-market.

Both of these developments raise interesting questions for social policy analysts. Why have they come about? To what extent are they a response to the perceived failures in the old systems? If they are a response to these failures, are they a good response? More generally, do they represent a desirable set of developments accurately reflecting the changing context in which welfare states find themselves, or are the changes simply another symptom of the inexorable decline of state welfare?

Many of these issues have been discussed extensively elsewhere (especially with respect to quasi-markets) and I shall not repeat all the points made in those discussions here. Instead I want to use the fact of these changes to develop an argument that I do not think has been made before, at least not in this form; an argument that illuminates both the 'why' and the 'desirability' questions with respect to the changes, but one that also has broader implications for social policy in general. This concerns the assumptions that underlie welfare policy concerning the mainsprings of human behaviour.

More specifically, I argue that both the quasi-market and legal changes in welfare systems are based on a particular view of human motivation and behaviour, and that this view is rather different from the assumptions concerning motivation that underlay older models of welfare systems. However, neither this 'new' view nor the 'older' assumptions are likely to provide an adequate account of the way in which people actually behave in welfare-relevant situations; hence welfare systems based solely on one or the other are likely to fail. What is needed are 'robust' welfare policies: ones that allow for the possibility of different kinds of human motivation and hence have the potential for more successful outcomes.

This is a broad canvas. Inevitably in places the argument is speculative; equally inevitably it will involve both the caricaturing of distinguished thinkers' arguments and the over-simplification of a complex reality. However, it is hoped that the central ideas contain sufficient 
insight to justify their preliminary exposition here, and perhaps to stimulate their subsequent development.

The article begins with a brief exposition of the two sets of changes that are our jumping-off point. The next section develops the main argument, while the following two sections examine some possible implications for policy. There is a brief conclusion.

\section{QUASI-MARKETS}

Throughout the development of British welfare policy, the state not only financed the supply of social services such as education, health care and social care, it provided them as well. That is, it owned and operated most of the institutions and agencies that provided these services, and employed the staff who worked in them. In many areas of welfare it was effectively a large, monopoly provider and, as such, inevitably attracted the kinds of criticisms that such organisations tend to attract: that they are wasteful, inefficient and unresponsive to the needs and wants of users. Partly in response to such criticisms, in the late 1980 s and early 1990s, state provision was systematically replaced by a more market-oriented, competitive approach to service delivery: the quasi-market.

In a quasi-market, the state retains control of finance, either by giving individuals vouchers or, more commonly, by appointing informed agents to purchase services on behalf of final users. Examples include vouchers for nursery education, open enrolment and formula funding for primary and secondary education (effectively another form of voucher), health commissions and GP fund-holders in the National Health Service, and social service departments, and care managers in community care. Provision of the service, on the other hand, is not undertaken by the state, but is left to independent providers (profit and non-profit) who compete with one another for the custom of purchasers. Examples include hospital trusts, locally managed and opted out schools, and private and voluntary residential homes for those in need of social care. The intention behind the introduction of quasimarkets is that the process of competition in provision will promote efficiency and responsiveness, while the state can ensure equity through judicious use of the mechanisms for financing purchasers.

This process has been discussed in more detail elsewhere (Le Grand and Bartlett, 1993; Glennerster and Le Grand, 1995) and I will not dwell further on it at this point. In the meantime let me describe briefly another change that perhaps is only on the horizon at the moment, but could become as significant for the social security side of 


\section{Julian Le Grand}

the welfare state as the quasi-market developments have been for the social services side: the growth of 'legal' welfare.

\section{'LEGAL' WELFARE}

As many writers have pointed out, ${ }^{2}$ the postwar system of social security was built on a number of fundamental assumptions concerning the social and economic environment in which it would operate. First, Keynesian macro-economic policies would ensure that there would be full employment. Second, the family would continue to exist in broadly its pre-war form, with a male bread-winner and a female home-maker and child-carer (Glennerster, 1995, pp. 34-5: Lowe, 1993, pp. 33-55). Third - and the centrality of this assumption has been less widely remarked (but see Glennerster, 1995, p. 41) - there would be no fundamental shifts in 'market' inequality: the underlying differences in income and wealth generated in the market and that the social security system was in part designed to correct. In particular, earnings differentials would remain unchanged, or, more likely, narrow as widespread equality of educational opportunity ensured that job skills became more widely diffused.

Recent reports from the Commission on Social Justice (1994) and the Joseph Rowntree Foundation (1995) have brought to the attention of a wider public what economists and social policy analysts have known for some time: that these assumptions no longer hold. Full employment disappeared in the 1970s. There now appears to be a hard core of long-term unemployed and a larger group of temporarily unemployed, whose composition changes; although currently falling in size, both groups remain stubbornly large (Commission on Social Justice, 1994, pp. 33-5; Joseph Rowntree Foundation, 1995, II, ch. 5). Women have entered the labour force in large numbers; hence they are no longer as available to look after children (or other dependants, such as elderly relatives) (ibid.). Family break-up is widespread; and the number of single-parent headed households is increasing sharply. And, perhaps most profound of all, labour market inequality is widening dramatically. As the Commission on Social Justice has noted (1994, p. 28):

For nearly forty years after the Second World War, the income gap between the richest and the poorest in the UK gradually narrowed. That progress has now been reversed. Today, the gap between the earnings of the highest-paid and those of the lowest-paid workers is greater than at any time since records were first kept in 1886.

Awareness of the limitations of the social security system, and its consequent inability to deal properly with the dramatic increases in 
inequality and poverty, has led to a growing interest in welfare interventions of a rather different kind. One, directed at wage inequality, is the minimum wage, long advocated on the left, but now gaining support from a much wider group of labour market analysts (see, for instance, Card and Krueger, 1995). Another, aimed at reducing unemployment, is a legal limit on the working week, an approach now attracting attention in the Netherlands and France. In Britain, Australia and elsewhere, the financial difficulties of single parents are being addressed by statutory bodies such as the Child Support Agency; and in Britain measures have been proposed to make divorce more difficult, especially for couples with children. There is also a developing interest in Anglo-Saxon countries in the obligation alimentaire: the principle, common in continental Europe, that adults have a financial obligation to support their elderly parents. Singapore is now considering introducing a similar scheme, but with the obligation being legally enforced.

What all these apparently rather disparate measures have in common is that they do not wait until income is 'delivered' by the market to families or households, and then, like the current welfare state, redistribute it through fiscal measures such as taxes and social security benefits. Instead they use legal measures to intervene directly in the process by which people get an income - directly in the primary income distribution. So minimum wages and limits on working hours affect the amounts that employees obtain from their work; the Child Support Agency, restrictions on divorce and the obligation alimentaire compel people to support their dependants directly. In other words, such measures deliver welfare through legislation or regulation and not through the fiscal system: hence their description as forms of 'legal' welfare. $^{3}$

Again there is not the space here to discuss this phenomenon in detail; I hope to return to it in future work. Instead, let us turn to the main focus of this article: the difference between the assumptions concerning human motivation and behaviour that underlay these 'new' forms of welfare and those that informed the 'old' welfare state that they may be replacing.

KNIGHTS, KNAVES OR PAWNS?

Assumptions concerning human motivation and behaviour are the key to the design of social policy. Policy-makers fashion policies on the assumption that those affected by the policies will behave in certain ways and they will do so because they have certain motivations. 


\section{Julian Le Grand}

Sometimes the assumptions concerning motivation and behaviour are explicit; more often they are implicit, reflecting the unconscious values or beliefs of the policy-makers concerned. Conscious or not, the assumptions will determine the way that welfare institutions are constructed. So, for instance, a welfare state constructed on the assumption that people are motivated primarily by their own selfinterest - that they are, in the words of David Hume quoted at the beginning of this paper, knaves ${ }^{4}$ - would be quite different from one constructed on the assumption that people are predominantly publicspirited or altruistic - that they are what we might term knights in contrast to knaves. Similarly, if policy-makers work on the assumption that people are essentially passive or unresponsive - neither knights or knaves, but pawns - then again the policy concerned would be quite different from one designed on the assumption that human beings respond actively to the incentive structures with which they are faced. ${ }^{5}$

It might also be noted that these assumptions - or, more precisely, the relationships between the assumptions and the realities of human motivation - are crucial to the success or otherwise of the policies concerned. Hume was keen to point out that policies designed on the assumption that people are knights are likely to have disastrous consequences if in fact they are predominantly knaves. But, as Richard Titmuss was anxious to emphasise in The Gift Relationship (whence came the quotation at the beginning of the article), the same is true for policies fashioned on the basis of a belief that people are knaves if the consequence is to suppress their natural altruistic impulses.

We shall return to these points later. In the meantime, the importance of the beliefs about human behaviour involved in policy-making can be illustrated by comparing those implicit in the old-style welfare state that preceded the changes discussed above, and those implicit in the new, post-reform, welfare systems. Inevitably given their implicit nature, it is difficult fully to document any claims that one might wish to make about these beliefs by reference to explicit statements by policy-makers or others; hence such claims must at times remain more at the level of assertion than of scientifically established fact. However, it is hoped that the rather stylised set of pictures that are painted here have enough accuracy so as not seriously to distort the scenes that they are trying to represent. ${ }^{6}$

Lowe (1993) has argued that there were two approaches to welfare that characterised the pre-reform British welfare state: the reluctant collectivists, pre-eminent among whom were Beveridge and Keynes, 
and the democratic socialists, who included Marshall, Titmuss and Crosland. Of these, he argued that:

despite the predominant influence of Beveridge and Keynes in the early postwar years, it was the democratic socialists which gave the British welfare state its unique international reputation. At home these ideals also infused the welfare legislation of the 1954-61 Labour governments and provided the logic for further advances which the Conservative ministers struggled to refute. (Lowe 1993, pp. 18-20)

In Lowe's view, it was the social democratic approach, albeit tempered by that of the reluctant collectivists, which determined the evolution of the postwar welfare state: 'social democracy had history on its side' (ibid.).

What then were the assumptions concerning human behaviour implicit in the 'democratic socialist' welfare state? In trying to answer this question, it is useful to distinguish three sets of actors. First, there were those who operated the welfare state: the politicians and civil servants who devised its policies, the managers who administered it, and the professionals and others who delivered its services. Second, there were those who paid for welfare: taxpayers under the fiscal welfare system. Third, there were those who received the benefits of the welfare state: social security recipients, doctors' patients, school pupils and their parents, council house tenants and so on.

Democratic socialists assumed that the state and its agents were both competent and benevolent (Lowe, 1993, p. 23). Hence it followed that the first group - those who operated the welfare state - could be trusted to work primarily in the public interest (Donnison, 1982, pp. 20-1). Professionals, such as doctors and teachers, were thought to be primarily motivated by their professional ethic and hence to be concerned only with the interests of the people they were serving. ${ }^{6}$ Similarly, politicians, civil servants, and bureaucrats and managers were supposed accurately to define social and individual needs in the areas concerned, and to operate services that did the best possible job of meeting those needs from available resources.

The second group - the taxpayers - were also assumed to be part of the collective view that 'social justice would be guaranteed by a predominant altruism' (Lowe, 1993, p. 19) and hence to accept a growing burden of progressive taxes (Donnison, 1982, pp. 20-1). ${ }^{8}$ More specifically, it was assumed that the better-off would not only co-operate in collectivist enterprises such as national insurance and social services but also acquiesce in paying redistributive taxation that helped the disadvantaged, either because they empathised with the latter's plight or because they saw it as part of their civic responsibility to do so. 
The democratic socialists did not assume that the third group individuals in receipt of the benefits of the welfare state - were active altruists. Rather, the latter were considered to be essentially passive: pawns, not knights. Those who used social services were supposed to be content with a universal, often fairly basic, standard of service. So Titmuss, for instance, spoke of the desirability of 'one publicly approved standard of service' (1968, p. 195). In practice, with respect to the National Health Service, for instance, this meant that patients were supposed to live up to their appellation and be patient. They were to wait patiently in queues at GPs' surgeries or at outpatient clinics; if they needed further treatment, they had to wait for their turn on hospital waiting lists. When the time arrived for them actually to go to hospital, they were supposed cheerfully to accept being on a public ward, being served horrible food and, most significantly, being treated by doctors too busy, or too elevated, to have time to explain what was happening to them. As Klein has put it, in the early model of the NHS: 'it would be the doctor's judgement which would determine who should get what...It was the experts who determined the need for health care, frame the appropriate priorities and implement their policies universalistically throughout the NHS' (Klein, 1995, p. 248). ${ }^{9}$

Similarly, the parents of children in state schools were expected to trust the professionals, and to accept that teachers knew what was best for their children. The period between 1944 and 1975 was identified as the 'golden age of teacher control'. ${ }^{10}$ Moreover, as with the NHS, especially following the comprehensive reforms of the mid-1960s, parents were supposed to concur that 'the overriding objective in [education policy] was equality' (Lowe, 1993, p. 203) and hence to accept whatever degree of uniformity of educational provision that attaining this objective required.

Council house tenants were expected to be grateful for the privilege they had been accorded in being granted a tenancy (Dunleavy, 1981, pp. 28-33). Their accommodation was standardised, with heavy restrictions as to their freedom of action over what could be done with it. ${ }^{11}$ And again the experts were presumed to know best about the housing that people wanted. ${ }^{12}$

At least for some of the democratic socialists, similar views characterised their beliefs about social security recipients. As Deacon has recently argued, Titmuss, for instance, assumed that the beneficiaries of social security had very little choice at all; that the economic and social system was so all powerful that they were simply its victims; that they had no freedom of action and hence were simply passive recipi- 
ents of state largesse (Deacon, 1993). ${ }^{13}$ However, it has to be acknowledged that this view does not seem to characterise the actual delivery of social security policy. The postwar history of the latter (and indeed the entire history of social security) is peppered with the development of different forms of checks and balances to control the perceived problem of the people variously termed the workshy, loafers or scroungers (Deacon, 1976; Bryson and Jacobs, 1992; Jacobs, 1994). Here there seems to have been a constant tension between the assumption that welfare recipients were basically passive - pawns - and the assumption that they were active agents in pursuit of their own self-interest: knaves.

Social security, therefore, is perhaps a partial exception. But it is not implausible to describe the bundle of implicit assumptions concerning human behaviour that characterised the rest of the democratic socialist welfare state as one designed to be financed and operated by knights, for the benefit of pawns.

However, recent years have seen serious assaults on all of the assumptions that underlay the democratic socialist welfare state (Glennerster, 1995, pp. 193-5; Lowe, 1993, pp. 23-7; Timmins, 1995, Part V). The notion that, for the sake of the collectivity, everyone would passively accept standardised, relatively low levels of services was challenged by studies showing that in key areas of welfare the middle classes extracted at least as much if not more than the poor in terms of both the quantity and quality of service (Le Grand, 1982). More generally, it became increasingly apparent that many people - particularly, but not exclusively, the middle classes - wanted different kinds and different levels of service. Richard Titmuss himself may have enjoyed being in a public ward (Titmuss, 1974, p. 151) but many people did not. The length of waiting lists for medical treatment became a perennial political issue. Many of the better off put their children in private schools and took out private health insurance; many more subscribed to occupational pensions (although often this was a condition of service). The consensus supporting comprehensive education began to break down, with influential voices encouraging an end to teacher control over the curriculum, a return to selection, traditional teaching methods and a focus on excellence (Timmins, 1995, pp. 318-29). As council estates declined and tenants felt increasingly powerless, owneroccupation became overwhelmingly the preferred form of housing tenure (Power, 1995, pp. 212-14).

The assumption that knightly behaviour characterised those who worked within the institutions of the welfare state proved even more 


\section{Julian Le Grand}

vulnerable. Fuelled in part by people's experience both of dealing with, and of working within, the welfare bureaucracies, scepticism grew concerning the belief that bureaucrats and civil servants necessarily operated in the public interest, and that professionals were only concerned with the welfare of their clients (Glennerster, 1995, p. 193). Instead, there was an increasing acceptance of the argument of the public choice school of economists and political scientists that the behaviour of public officials and professionals could be better understood, if the assumption was made that they were largely self-interested (Lowe, 1993, pp. 22-3). ${ }^{14}$

The idea that knightly behaviour characterises those who pay for welfare was also challenged. Goodin and Dryzek (1987), and, more comprehensively, Baldwin (1990), argued that the postwar growth of tax and social insurance funded welfare states in a wide variety of developed countries was not the outcome of altruistic gestures by the better-off; rather it was directly related to the self-interest of the middle classes. Econometric studies by Peltzman (1980) and Pampel and Williamson (1989) came to similar conclusions. A more micro-level study undertaken by Winter and myself of changes in public expenditure and tax reliefs under the first Thatcher administration, based on the assumption that politicians were vote-maximising, found a pattern of change that unequivocally favoured the better-off (Le Grand and Winter, 1987).

Even more recently, tax-payer resistance to redistributive welfare has become an accepted political fact, on the left as well as the right. For instance, Piachaud argued in a recent Fabian pamphlet that 'there is now virtually no likelihood of further substantial redistribution of income through taxes and social security benefits' (1993, p. 3); a judgement he based not on technical impossibility or social undesirability, but simply on political feasibility. Field has gone further, claiming that politicians who argue that the middle class will support redistribution to the poor are a 'public menace, distracting from the real task' (1995, pp. 1-2).

Finally, the idea that people in receipt of social benefits are pawns, and that they do not respond to any incentives or disincentives built into the system has also been vigorously assaulted. Again, although the assault began on the Right, with Murray's book Losing Ground (1984) as a notable example, it has been taken up in other parts of the political spectrum; see, for instance, Etzioni's The Spirit of Community (1994) and the works of Deacon (1993) and Field (1995) already mentioned. 
How does all this relate to the growth of quasi-markets and the growth of interest in legal welfare? Both these phenomena can be viewed in some sense as the replacement of what might be called knight-and-pawn strategies with knavish ones. Thus fiscal welfare welfare based on taxation and social security - involves a system of redistribution whose long-term sustainability depended on people's sense of altruism, or at the least of collectivity. Legal welfare, on the other hand, is a redistributive mechanism where specific groups of individuals are identified as having responsibility for redistributing to another group and who are then, in case they knavishly duck out of those responsibilities, coerced by legal means to make the appropriate transfer. Thus poverty due to low pay is assumed to be the outcome of employers knavishly exploiting their employees; hence a minimum wage is introduced to transfer income from employers to employees (the fact that in practice minimum wages actually transfer incomes in more complicated ways than that is irrelevant since we are only concerned here with the perceptions of the relevant policy-makers and their supporters). Similarly, instead of viewing the children of single mothers as part of a collective responsibility and to be paid for accordingly, they are regarded as their father's responsibility; and, again to avoid fathers knavishly ducking their duties, their incomes are directly targeted as the source of maintenance by the Child Support Agency.

The knavish strategy implicit in the quasi-market agenda is rather different. This is not simply a coercive mechanism to repress knavery; rather it is an attempt to harness the knavery - or, to put it less pejoratively, the self-interest - of those working in the system to the public good. As with ordinary markets, quasi-markets are supposed to display the workings of Adam Smith's Invisible Hand, whereby, simply through pursuing their own advantage, suppliers are led to contribute to socially desirable ends. Thus managers and doctors working in trust hospitals that are losing money are assumed, in their own self-interest, to become more responsive to the wishes and wants of their purchasers and the people they represent. They will also strive to be more efficient and less wasteful in their use of resources so as to ensure they stay within budget (or make a surplus, if they are allowed to keep it). Schools will be more sensitive to parents, for fear that they will otherwise take their child away - or not apply in the first place - and the school budget will suffer. And they too will have an incentive to be more efficient.

So part of the why question - why these new forms of welfare developed when they did - can be explained as a reaction to what might be 
termed a loss of faith in the benevolence of human nature. This switch in belief - that people are closer to being knaves than being either knights or pawns - led policy-makers to switch welfare strategies: a switch that it is probably only slightly caricaturing to describe as one from policies designed to be financed, and staffed by knights and used by pawns, to ones financed, staffed and used by knaves.

\section{WELFARE STRATAGIES}

So much for the why question. What of the desirability question: are these 'knaves' strategies', as Pettit (1996) has called these kinds of institutions, desirable? In his recent book Making Welfare Work, Field has argued that, for welfare reform,

the starting block is a willing acceptance of the fundamental role self-interest plays in human motivation. The job of a welfare reconstruction is to plan a series of benefit reforms which allow self-interest to operate in a way that simultaneously promotes the public good. (1995, p. 20)

A central question is therefore: are Field and the others who think like him and who, by implication, do not think like the democratic socialists, right, while Titmuss, Marshall and the other democratic socialists are wrong?

There have been enormous amounts written on the merits and demerits of some of the specific policy instruments we are talking about, such as purchaser/provider splits in the health service, minimum wages as a means for helping the poor, or the Child Support Agency. They cannot be all summarised here; nor would that be appropriate for this article. Rather my intention is to continue with the more general theme concerning the relative merits of strategies based on different assumptions about human behaviour.

Now one might at first think that the most obvious way of settling any debate about the merits of these two kinds of policies is to ascertain which of the assumptions on which it is based are correct. Are people in fact knaves, knights or pawns - or some combination of all three? We have seen that there has been a shift in belief among many decision-makers and opinion-formers towards the view that, in most situations of relevance to welfare, the individuals concerned are more likely to be self-interested than public-spirited; but is this change in belief well founded?

Even to ask these questions is to invite the charge of over-simplification. Perhaps in consequence, few of the protagonists in the debate refer to psychological evidence concerning what does actually motivate 
people in different situations. It may be that such evidence does not exist; or, perhaps more likely, that such evidence that does exist is not amenable to simple interpretation. Nor, so far as I can ascertain, have there been many attempts to test the theories derived from the different assumptions by deriving predictions from the theories and testing them against the empirical record.

So for the moment I think we have to assume that we do not know whether, in welfare-relevant situations, people actually will behave as knights, knaves, pawns or indeed in some more complex fashion. What does that imply about the appropriate welfare strategy to adopt?

One possible implication is that, in a situation of ignorance concerning human motivation, it would be safest to adopt public policies based on the knaves strategy. For a knaves strategy will do little harm if people are actually knights; but a knights strategy could be disastrous if people are actually knaves.

That a knights strategy will fail if most people are in fact knaves is reasonably self-evident. That a knaves strategy could work even if most people are knights, is perhaps less obvious, and is perhaps best illustrated by an example. Take a particular group of people involved in some welfare institution, say doctors in a hospital. Now suppose that most of these doctors are in fact knights, doing the best they can for their patients, often at considerable personal sacrifice. Moreover, the reward structure of the hospital is actually based on that assumption, with automatic payment of salaries and with no monitoring of doctor behaviour or performance review. But suppose, too, that there are a few consultants who are knaves, spending their time on the golf course or managing their investment portfolio, to the obvious detriment of their patients; behaviour that, despite the fact that it is only characteristic of a small number of doctors, is damaging the performance and reputation of the hospital as a whole, and thereby threatening its survival.

Now suppose in this situation that a system is introduced of performance-related pay. Since they are not motivated by economic self-interest, this will leave the knights' motivational structure untouched: they will still derive the same reward as before from doing good to patients. They will therefore carry on undertaking to the best of their ability all the activities that are part of what they perceive as their duty to patients. The knaves, on the other hand, will see that it is now in their self-interest to perform their duties properly and will react accordingly. What the new structure will have done, therefore, is bring the knaves into line, ensuring that they perform as least as well as the knights. 


\section{Julian Le Grand}

Everybody, knights and knaves, are now performing to the best of their ability; and the hospital is saved.

However, in practice things may not always be that simple. The principal problem with the example is that it assumes there will be no impact of the introduction of the knave strategy on knightly behaviour. More specifically, the assumption is that, after the introduction of performance-related pay the knights will carry on as before; only knaves are affected. But this may not be the case: the introduction of a knavedirected strategy may make the knights behave more knavishly (Goodin, 1996, pp. 41-2; Pettit, 1996, pp. 72-5). A knightly doctor whose pay rises dramatically as a result of the introduction of performance-related pay might wonder whether she had not been selling herself short under the old regime or putting in an excessive effort. Further (again following Pettit, 1996), thinking about these questions may make her start paying attention to the promotion of her own selfadvantage in the new situation.

Of course, this is similar to a central point in Titmuss' The Gift Relationship. It will be recalled that this was written partly in response to an Institute of Economic Affairs publication, by two health economists, Cooper and Culyer (1968). This advocated the supplementation of the British system of blood donation with a market system, involving, among other things, paying potential 'donors' for their blood. Titmuss argued, I think convincingly, that, in a system where people give blood and do so primarily for altruistic reasons, then the introduction of a system of payment for blood may make those voluntarily contributing their blood reconsider their position and perhaps reduce their contribution or even stop altogether.

Now it could be argued that, in one sense, even if something like this does occur in these situations, it does not matter. Even if the introduction of a knaves strategy does have the consequence of turning knights into knaves, then, so long as the incentives for knaves are the right ones, performance will continue to improve. For the newly created knaves will respond to the self-interested incentive structure in the same way as the old established knaves: hence the outcome will be the same as if they had remained knights.

But there are two objections to this kind of argument. First, even if the eventual outcome is the same, there is something distasteful about setting up a system that turns knights into knaves. Our society regards altruistic or public-spirited behaviour as morally superior to self-interested behaviour and deliberately to encourage the latter at the expense of the former seems perverse. Second, the argument assumes that the 
knaves strategy is watertight; that there is no way of getting round the system in a way that furthers self-interest but on this occasion at the expense of the public good. So, for instance, a system of performancerelated pay requires reliable and accurate procedures for measuring and monitoring performance; one that cannot be fiddled to indicate better performance than is actually happening. But - as is apparent from the example - watertight systems are not always easy to construct, or maintain. So I am not convinced that the answer to the problem of our ignorance about human motivation lies in the wholesale adoption of knaves strategies.

A second possibility is to adopt or to continue with knights strategies, and to try by other means to ensure that people actually behave more like knights. This is close to the views of another new entrant to the 'vision' industry: Amitai Etzioni and his communitarian movement (1994). Etzioni argues that, in our present society, individuals are much more concerned with their rights than with their responsibilities: with their own needs rather than the needs of others. In his view, people need to be re-educated in the civic virtues; in the language of this article, they need to be converted - or maybe re-converted - from knaves into knights.

Etzioni is vague as to precisely how this is to be done. But it seems that legal welfare could be viewed as a useful tool for this purpose. Of course in one sense it is a device for making knaves behave like knights through coercion. Through minimum wages and maximum working weeks, legal welfare forces employers to pay decent wages and not to over-work their employees; the Child Support Agency compels errant fathers to meet their child maintenance responsibilities. However, legal welfare could also have a more positive role as an expression of social leadership. By indicating through the legal system social disapproval of the practices concerned, it could help internalise that disapproval within individuals, thus helping convert the knave into the knight.

\section{ROBUST WELFARE POLICIES}

A third approach, and one that in some ways seems preferable to relying on strategies that appeal either only to knaves or only to knights, is to accept our ignorance about what actually motivates people and to try to design what might be termed robust strategies: strategies or institutions that are robust to whatever assumption is made about human motivation. ${ }^{15}$ Now this, of course, is far from easy. But, to show that it is not impossible, let me give four illustrations, two of existing policies and two proposals for reform. 


\section{Julian Le Grand}

The first of the current policies concerns the schemes introduced in the NHS to improve the premises of General Practitioners (GPs). There are two schemes: cost rents and improvement grants. The rules of the cost rent scheme are complex, but the effect of them is that a GP purchasing new premises receives an annual payment approximately equal to the interest that they would have paid if they had taken out a 100 per cent mortgage to finance their purchase. This is payable regardless of how the scheme is actually financed. Improvement grants are one-off cash payments to GPs to pay for up to two-thirds of the capital costs of improving surgery premises. They are available only to GPs who own their own premises.

Now these schemes appeal to both the knight and the knave in the GP. In each case, participating in the scheme results in an improvement in the premises concerned and thereby in services available to patients. Hence the knight is satisfied. However, in each case the GP owns the premises; hence the value of the property is enhanced and self-interest furthered. Both motivations work in the same direction.

It is no coincidence that these schemes have been very successful. For instance, a survey by Hambros (1992) found that $£ 620$ per annum per GP was being spent on the maintenance and refurbishment of GP suites in health centres. Whereas the comparable figure for spending through the cost rent and improvement grant schemes was $£ 6,500$.

The second example of an existing policy again concerns GPs, but this time in the role that some of them play as GP fund-holders. Under the scheme, GPs are allowed to keep any surplus on their funds, so long as they use it for any purpose that is beneficial to patients. Again this is a scheme that could appeal to the knight and the knave. The surplus could be invested in improving premises, thus benefiting both patients and GPs. Or it could be used to purchase new staff, thus easing the work-load of GPs, and thereby both making them feel better off and enabling them to provide a better service, or perhaps a more relaxed one. Again both the knight and the knave are appeased.

A third illustration of a 'robust' policy concerns proposals for funding of long-term care. This I shall discuss in a little more detail. It is clear that, in order to provide an adequate level of finance for such care, it will have to rely in part on private resources, both in financial terms and in terms of time and effort provided by informal carers. The trick is in some way to mobilise those resources (or to continue to mobilise them) in a fashion that both generates enough combined resources (public and private) to provide an adequate level of care for those who need it, and does not seem punitive in implementation. 
The problem with the current means-tested system in Britain is that it meets neither criteria. The level of provision of community care is universally regarded as inadequate. At the same time the means-test, which requires the running down of assets until their value falls below a certain level, seems to penalise those who have had the foresight to save for their old age, or for their children's inheritance, and is thus viewed as punitive and exploitative. Moreover, and of direct relevance to the theme of this article, it encourages people to behave knavishly: to engage in means-test avoidance, adjusting their means in such a way as to minimise the amount extracted by the state. What should be a noble act - the state helping those in need - becomes instead a sordid set of private activities of dubious morality and, often, even of doubtful legality.

One way of reforming the system is to introduce the version of legal welfare described earlier as the obligation alimentaire, under which those who can afford it are legally obliged to provide financial support to their relatives in need of care. But this would involve extending the means-test to relatives. Hence it would encourage people to behave knavishly, concealing their assets from 'the means-test man', as in the not dissimilar household means-test that disfigured the British welfare state of the 1930s.

A more attractive alternative is the introduction of what might be termed a 'partnership' or 'matching' scheme. This would involve a minimum level of public funding coupled with a system of matching grants for expenditure over that minimum. Under this system each person assessed as being in need of care would be entitled to a minimum level of care met from public funds. This minimum, although adequate, would be basic. For the payment of care above the minimum, the government would undertake to match $£$ for $£$ the resources that individuals or their relatives can mobilise for their own care. To keep spending under control, there would be an overall limit on the total amount of grant that could be received by any individual.

There are unattractive features of such a scheme. In particular, it gives more to those who contribute more, and hence it is likely to be less progressive than any means-tested scheme it might replace. However, it does have the merit of avoiding any form of compulsory means-tests, instead encouraging people voluntarily to contribute resources. More importantly from the point of view of this article, it could appeal to both the knight and the knave. It appeals to self-interest because it encourages people to provide for themselves. However, it also encourages relatives and friends to contribute resources to help 
people in need; and it appeals to a more collectivist spirit of altruism through the use of public money to provide the matching funds.

A similar idea could be applied to pensions. The state could continue to provide a minimum pension, as now, but also agree to match $£$ for $£$ (or at some other rate) any extra provision that an individual made for him or herself. As in the community care case, there would be a limit on the total offered to any one person.

The idea as applied to pensions has similar general advantages as when applied to long-term care. Moreover, in the pensions context it does not seem to have some of the difficulties of the long-term care context, particularly that relating to progressivity. There is also already what could be viewed as a crude form of partnership scheme, in the form of the various tax reliefs for occupational and private pensions. But, as is well known, tax relief is both regressive and a blunt instrument: it favours higher rate taxpayers, it does not benefit those who do not pay tax, it encourages lots of tax-avoidance schemes that have little to do with the essential tasks of social security, and its cost is difficult to control.

The total cost of these tax reliefs to the Treasury is now running at about half the total cost of the state pension. If this money were used instead for a matching grant system, this would (a) be more progressive, in that it would not favour higher rate taxpayers and would go to everyone, not just those who pay tax; (b) create a much more sensitive policy instrument; (c) eliminate incentives for tax avoidance, and indeed more generally reduce the incentives for knavery of one kind or another. Finally, of course, it is not resource-consuming; it is simply a redirection of existing resources in a more progressive and more policysensitive fashion.

Obviously, partnership ideas such as these require further development. However, together with the other examples given, they suggest, at the least, that the search for policies that are robust to different assumptions concerning human behaviour is not an impossible one.

\section{CONCLUSION}

The old welfare state was largely based on the assumptions that, in welfare-related situations, people would behave either like knights or like pawns. This article has discussed 'new' forms of welfare, some based on the assumption that people are knaves, some on the assumption that we can convert knaves into knights, and some on the assumption that we are ignorant about the mainsprings of human motivation. The last of these may not have the clarity, or even the 
moral appeal, of some of the others. But they are, I believe, more firmly grounded than the others and hence should offer a stronger foundation for a social and welfare policy aimed at what we all would like to achieve: the best possible health, education and welfare of all our citizens in the next century, be they knights, knaves or pawns.

\section{NOTES}

1 This is a revised version of an Inaugural Lecture given at the London School of Economics on 12 July, 1995, under the title 'New Visions of Welfare'. I am grateful to Alan Deacon, Ken Judge, Rodney Lowe, Peter Taylor-Gooby, Nicholas Timmins, to an anonymous referee, and to many colleagues in the LSE Department of Social Policy and Administration and the Kings Fund Policy Institute for helpful comments.

2 See, for instance, Glennerster (1995), especially chs. 1 and 2; Lowe (1993), especially chs. 5 and 6; Timmins (1995), especially Part I.

3 It should be noted that not all recent policy developments have taken this form; indeed, some have gone in the opposite direction, such as the abolition of wages councils in Britain. However these appear to be exceptions to the more general trends. The abolition of wages councils, in particular, reflected a political commitment by the government in power that significantly predated most of the reforms with which we are concerned.

4 Hume was not the first to use the term in this way. That honour is probably due to Bernard Mandeville, who described an ideal constitution as one "which remains unshaken though most men should prove knaves' (1731, p. 332, quoted in Pettit, 1996, p. 72).

5 Although I have generally tried to make my language gender-neutral, it is possible that some of the terminology used in this article (especially that involving the terms knights and knaves) conjures up a world peopled entirely by men. This is unintended - and, if it distorts the argument, unfortunate. For it is not implausible that the balance of human motivation differs significantly between the genders. Hence it might be appropriate to design welfare policies quite differently depending on the gender balance of the groups involved. This is an issue that requires more exploration.

6 Amateur historians of British postwar social policy such as myself are fortunate that three excellent histories of the welfare state since 1945 have been published recently - one by Rodney Lowe (1993), one by Howard Glennerster (1995) and one by Nicholas Timmins (1995) - as has a third edition of Rudolf Klein's superb study of the development of the National Health Service (1995). What follows draws heavily on all four.

7 It is useful here to follow Klein (1995, p. 243) and distinguish between attitudes towards professionals as individuals and as a collectivity. For instance, few of the politicians who had dealings with the collective organs of the medical profession, such as the British Medical Association, would have regarded them as public spirited altruists: indeed, in all probability they would have agreed with Enoch Powell when he wrote the unnerving discovery every Minister of Health makes at or near the outset of his term of office is that the only subject he is ever destined to discuss with the medical profession is money' (Powell, 1976 , p. 14). However, at the individual level the assumptions were different. For built in to the concordat that provided the foundations of the NHS was the assumption of clinical freedom or autonomy, whereby individual doctors could exercise their professional discretion in the way they use public resources (Klein, 1995, p. 243).

8 See also Reisman (1977), p. 91.

9 See also Glennerster (1995), p. 69.

10 Chitty (1988), quoted in Lowe (1993) p. 227. This was not just because it was assumed that teachers knew best: there was a fear of malign government influence. Timmins quotes the General Secretary of the National Union of Teachers arguing in 1954 that democracy is best safeguarded by 'the existence of a quarter of a million teachers who are free to decide what should be taught and how it should be taught' (1995, p. 323). 


\section{Julian Le Grand}

11 Cf. Anthony Crosland, writing in The Guardian in 1971 (and obviously forsaking his democratic socialist credentials), who said that the council 'decides what repairs are to be done, what pets may be kept, what colour the doors will be painted, what play areas there should be, where a fence should be put up. The tenant is not consulted. He has no right of appeal.' Quoted in Timmins (1995), p. 366.

12 Power (1995), especially ch. 19. Also, Timmins illustrates the point with the story of Nicholas Taylor, an assistant editor at the Architectural Review. He "proposed that some evidence should be sought on what people actually wanted, to go with an issue "on the best of current housing". He was scornfully dismissed by the proprietor with the words: "But we KNOW what should be done!"' (Timmins, 1995, p. 186).

13 For more on Titmuss's assumptions concerning motivation and behaviour, see Reisman (1977), including the preface by Robert Pinker.

14 For a useful review of public choice theory, see Mueller (1989).

15 To avoid possible confusion I should make it clear that this is a different terminology from that used by Robert Goodin when he deals with the broad issue of institutional design. For him a 'robust' strategy is one that is robust to change, involving policies that are 'capable of adapting to new situations' (Goodin, 1996, pp. 40-1). What I call a robust strategy is closer to what Goodin would term a strategy that shows 'sensitivity to motivational complexity' (ibid.).

\section{REFERENCES}

P. Baldwin (1990), The Politics of Social Solidarity: Class Bases of the European Welfare State 1875-1975, Cambridge University Press, Cambridge.

A. Bryson and J. Jacobs (1992), Policing the Workshy, Avebury, Aldershot.

D. Card and A. Krueger (1995), Myth and Measurement: The New Economics of the Minimum Wage, Princeton University Press, Princeton.

C. Chitty (1988), 'Central control over the school curriculum 1944-1987', History of Education, 17: 324.

Commission on Social Justice (1994), Social Justice: Strategy for National Renewal, Vintage/Institute for Public Policy Research, London.

M. Cooper and A. Culyer (1968), The Price of Blood, Institute of Economic Affairs, London.

A. Deacon (1976), In Search of the Scrounger: The Administration of Unemployment Insurance in Britain, 1920-1931, Occasional Papers in Social Administration no. 60, Bell and Sons, London.

A. Deacon (1993), 'Richard Titmuss: 20 years on', Journal of Social Policy, 22: 235-42.

D. Donnison (1982), The Politics of Poverty, Martin Robertson, Oxford.

P. Dunleavy (1981), The Politics of Mass Housing in Britain 1945-1975, Clarendon Press, Oxford.

A. Etzioni (1994), The Spirit of Community: The Reinvention of American Society, Simon and Schuster, New York.

F. Field (1995), Making Welfare Work: Reconstructing Welfare for the Millennium, Institute of Community Studies, London.

H. Glennerster (1995), British Social Policy since 1945, Blackwell, Oxford.

H. Glennerster and J. Le Grand (1995), 'The development of quasi-markets in welfare provision in the United Kingdom', International Journal of Health Services, 25: 203-18.

R. Goodin (1996) (ed.), The Theory of Institutional Design, Cambridge University Press, Cambridge.

R. Goodin and J. Dryzek (1987), 'Risk sharing and social justice: the motivational foundations of the post-war welfare state', in Goodin and Le Grand (1987), ch.3.

R. Goodin and J. Le Grand (1987), Not Only the Poor: The Middle Classes and the Welfare State, Allen and Unwin, London.

Hambros (1992), Report to the Department of Health: Review of Funding of Accommodation of General Practices in Health Care in England, Hambros Bank Ltd for the Department of Health, London.

D. Hume (1875), 'On the independency of parliament', in T. H. Green and T. H. Gross (eds.), Essays, Moral, Political and Literary, vol. I, Longmans, London. 
J. Jacobs (1994), 'The scroungers who never were: the effects of the 1989 Social Security Act', in R. Page and J. Baldock (eds.), Social Policy Review 6, ch. 7.

Joseph Rowntree Foundation (1995), Income and Wealth, vols. I and II, Joseph Rowntree Foundation, York.

R. Klein (1995), The New Politics of the NHS (3rd edn), Longmans, London.

J. Le Grand (1982), The Strategy of Equality, Allen and Unwin, London.

J. Le Grand and W. Bartlett (1993), Quasi-Markets and Social Policy, Macmillan, Houndmills.

J. Le Grand and D. Winter (1987), 'The middle classes and the welfare state under Labour and Conservative governments', Journal of Public Policy, 6: 399-430.

R. Lowe (1993), The Welfare State In Britain since 1945, Macmillan, Houndmills.

B. Mandeville (1731), Free Thoughts on Religion, the Church and National Happiness, (3rd edn), London.

D. Mueller (1989), Public Choice II, Cambridge University Press, Cambridge.

C. Murray (1984), Losing Ground, Basic Books, New York.

F. Pampel and J. Williamson (1989), Age, Class, Politics and the Welfare State, Cambridge University Press, Cambridge.

S. Peltzman (1980), 'The growth of government', Journal of Law and Economics, 23: 209-87.

P. Pettit (1996), 'Institutional design and rational choice', in Goodin (1996), ch. 2.

D. Piachaud (1993), What's Wrong with Fabianism? Fabian Pamphlet no. 558, Fabian Society, London.

R. Pinker (1977), 'Preface', in Reisman (1977).

J. Enoch Powell (1976), Medicine and Politics: 1975 and After, Pitman Medical, London.

A. Power (1995), Hovels to High Rise: State Housing in Europe since 1850, Routledge, London.

D. Reisman (1977), Richard Titmuss: Welfare and Society, Heinemann, London.

N. Timmins (1995), The Five Giants, HarperCollins, London.

R. Titmuss (1968), Commitment to Welfare, Allen and Unwin, London.

R. Titmuss (1971), The Gift Relationship, Allen and Unwin, London.

R. Titmuss (1974), Social Policy, Allen and Unwin, London. 